\title{
Barbara Obtułowicz, Maria Amparo Muñoz y de Burbon Księżna Czartoryska, wyd. Towarzystwo Autorów i Wydawców Prac Naukowych UNIVERSITAS, Kraków 2013,
} ss. 294

(c) $(1) \Theta$

http://dx.doi.org/10.12775/KLIO.2014.065

B arbara Obtułowicz jest profesorem Uniwersytetu Pedagogicznego im. B KEN w Krakowie. Jako historyk i hispanista prowadzi badania dotyczące zagadnień społecznych, kulturowych, a przede wszystkim polityczno-dyplomatycznych związanych z kobietą hiszpańską okresu romantyzmu. Obszarem jej zainteresowania jest historia XVIII i XIX-wiecznej Hiszpanii i Ameryki Łacińskiej. W swoich pracach opiera się na dokumentach rękopiśmiennych z archiwów Hiszpanii, Francji, Watykanu, Ameryki Łacińskiej i Polski. Jest autorką recenzji, wielu artykułów w czasopismach polskich i zagranicznych oraz trzech monografii.

Recenzowana książka została napisana - jak podkreśla autorka - aby przybliżyć czytelnikowi postać księżnej Władysławowej Czartoryskiej. Całość podzielona jest na trzy części, w pierwszej opisana jest historia rodziców Marii Amparo, dzieje ich poznania, miłości, morganatycznego małżeństwa. W drugiej części znajdujemy informacje o dzieciństwie i młodości, a w trzeciej o okresie, w którym Amparo jest już żoną księcia Władysława Czartoryskiego.

Maria Amparo Muñoz y de Burbon urodziła się w pałacu Pardo pod Madrytem jako pierwsze dziecko Marii Krystyny Burbon, królowej regentki i jej męża Augustína Fernanda Muñoz y Sánchez. Związek rodziców był morganatyczny, królowa wdowa poślubiła członka swojej straży. Małżeństwo zostało zawarte potajemnie i przez długi czas utrzymywane było w tajemnicy, podobnie jak dokładano starań, aby informacje o przyjściu na świat kolejnych dzieci nie ujrzały światła dziennego. W księgach chrztu ich imiona i nazwiska były zmienione, podobnie jak imiona i nazwiska rodziców. Prawda o ślubie królowej regentki i poddanego oraz o ich 
dzieciach wyszła na jaw, gdy Izabela następczyni tronu osiągnęła wiek, w którym mogła samodzielnie rządzić.

Maria Amparo, tak jak reszta rodzeństwa, wychowywała się bez obecności rodziców. Dzieci ukryte przed światem w domu, do którego nie mógł wejść nikt obcy, spędzały czas na nauce i pisaniu listów. W korespondencji tej przebija ogromna tęsknota za matką, Pan Augustyn codziennie mówi mi, że przyjedziesz i ten dzień nigdy nie nadchodzi ${ }^{I}$.

Gdy jej najstarsza siostra królowa Izabela samodzielnie rozpoczęła rządy, rodzice Marii Amparo mogli ujawnić, że są małżeństwem oraz przedstawić światu swoje dzieci. Cała rodzina przeniosła się do Hiszpanii, gdzie zaczęli bywać na balach organizowanych w pałacu królewskim. Kolejnym zwrotem w życiu Amparo był przymusowy wyjazd do Francji w związu z oskarżeniami Hiszpanów kierowanymi pod adresem jej rodziców. Dzieci wyjechały jako pierwsze, a za nimi podążyli rodzice. Maria Krystyna chciała jak najlepiej wydać za mąż najstarsze córki. Zainteresowała się Władysławem Czartoryskim, synem Adama Czartoryskiego, założyciela Hotelu Lambert. To z jej inicjatywy został zorganizowany obiad na neutralnym gruncie, u bratanicy Napoleona I, księżnej Matyldy Bonaparte, na którym u gospodyni zjawili się Władysław z rodzicami oraz Maria Krystyna z mężem. Amparo i Milagros miały dojechać później, gdyż ich suknie nie były gotowe. Panny bardzo się spóźniały i ostatecznie przyjechała tylko Maria Amparo. Jej osoba zrobiła ogromne wrażenie na Władysławie. Zaręczyny odbyły się wkrótce, a świadkami na ślubie była hiszpańska para królewska.

W czasie trwającego dziesięć lat małżeństwa, zakończonego przedwczesną śmiercią księżnej, Maria Amparo bardzo wspierała męża w jego działaniach na rzecz Polski. Wielokrotnie była jego pośredniczką i emisariuszką. Zmarła 19 sierpnia 1864 roku otoczona rodziną, jej ciało wystawiono w Hotelu Lambert, a 24 sierpnia odbyła się msza żałobna w kościele św. Ludwika, którą celebrował biskup Montpellier. Po jej zakończeniu orszak udał się do Malmaison, gdzie następnego dnia pochowano ją w rodzinnym grobie obok czterech młodszych braci. Później Władysław prze-

${ }^{1}$ Cyt. za: B. Obtułowicz, Maria Amparo Muñoz y de Burbon Księżna Czartoryska, Kraków 2013, s. 42. 
niósł jej ciało do Sieniawy, gdzie został pochowany również on i jego druga żona Małgorzata Orleańska.

Autorka książki Maria Amparo Muñozy de Burbon Księżna Czartoryska postawiła sobie za cel przybliżenie czytelnikom postaci pierwszej żony księcia Władysława Czartoryskiego. Do napisania biografii skłoniła Barbarę Obtułowicz chęć ukazania całego życia Marii Amparo, gdyż jedyna do tej pory wydana monografia na temat księżnej obejmuje tylko okres po ślubie z Władysławem². Autorką tej monografii, dzieła o życiu dwóch żon Władysława Czartoryskiego, jest Jolanta Lenkiewiczowa. W literaturze postać Marii Amparo pojawia się bardzo rzadko, odnajdujemy ją u Gabrieli Makowieckiej $^{3}$, Piotra Sawickiego ${ }^{4}$ czy przy okazji publikacji odnośnie do jej syna bł. Augusta Czartoryskiego. Przykładem może być książka Btogostawiony ksiadz August Czartoryski, Patron trudnego powotania pod redakcją ks. S. Wilka5.

Książka Barbary Obtułowicz to pierwsza pełna biografia księżnej. Napisana została na podstawie archiwów hiszpańskich i polskich. Autorka korzystała z materiałów rękopiśmiennych, wśród których najważniejszą rolę odegrały listy pisane przez Marię Amparo, rodzinę Muñozów y de Burbon i Czartoryskich. Informacje na temat księżnej znajdowała również w ikonografii oraz w źródłach drukowanych, takich jak pamiętniki i prasa.

Książka składa się z trzech części, pierwsza - najkrótsza - przedstawia przyszłych rodziców Marii Amparo. W drugiej, nieco dłuższej części, zawarte jest dzieciństwo oraz okres po ujawnieniu małżeństwa i dzieci w nim zrodzonych. W ostatniej, trzeciej części, autorka opowiedziała o życiu po ślubie z Władysławem Czartoryskim, o tym, jaką była żoną, matką, jak włączała się w walkę męża o sprawę polską, a kończy się próbami ratowania życia i o przegranej walce z chorobą. Części ułożone są chronologicznie. Książka, choć wielu czytelnikom biografie kojarzą się z nudą i rozczarowaniem, jest ciekawa i czyta się ją jednym tchem. Ukazuje osobę, która do tej

2 J. Lenkiewiczowa, Dwie księżne Czartoryskie, Warszawa 2000.

3 G. Makowiecka, Po grogach polsko-hiszpańskich, Kraków 1984, s. 312.

${ }^{4}$ P. Sawicki, Polacy a Hiszpanie. Ludzie, podróże, opinie, Wrocław 1995, s. 54.

5 Btogostawiony ksiadz August Czartoryski, Patron trudnego powotania, red. ks. S. Wilk, Lublin 2006, s. 32, 36, 59. 
pory pozostawała na uboczu. To właśnie dla takich postaci warto prowadzić badania, pisać ich życiorysy, po które z przyjemnością będą sięgali miłośnicy czytania. Sama historia jest niezwykle pasjonująca, a autorka sposobem, w jaki pisze, powoduje, że w czytelniku budzi się chęć, aby dowiedzieć się więcej. Warsztat, którym posługuje się prof. B. Obtułowicz, sprawia, że każdy fakt z życia księżnej poparty jest źródłem, ale jednocześnie nie jest to wyliczanka informacji czy zbiór zdarzeń historycznych, jest to piękna opowieść o życiu, miłości, rodzinie i jej losach osadzona w historii.

W zakończeniu prof. Obtułowicz jeszcze raz uwypukla najistotniejsze fakty z życia Amparo: młodość księżniczki, włączenie w sprawę polską, nadzieje rodziny Czartoryskich, księżna jako matka błogosławionego syna. Jednocześnie wymienia powody, dla których Maria Amparo była do tej pory tak mało znana, wśród nich: fatalna opinia o jej matce oskarżonej o działanie na niekorzyść Hiszpanii.

Bogata bibliografia zachęca do prowadzenia dalszych badań nad życiem hiszpańskiej księżniczki. Na szczególną uwagę zasługuje pieczołowitość, z jaką autorka zgromadziła niezbędne do napisania pracy archiwalia. W swoich badaniach nie tylko sięgnęła do zasobów archiwów znajdujących się na terenie Polski, ale również, a może przede wszystkim, oparła się na zbiorach archiwów zagranicznych. $\mathrm{Z}$ rodzimych były to Biblioteka Kórnicka, z której pochodzi większość fotografii zamieszczonych w książce, Biblioteka Czartoryskich w Krakowie, bogata w listy pisane przez Marię Amparo i członków rodziny Czartoryskich czy Fundacja XX Czartoryskich w Krakowie. Dzięki studiom, które prowadziła prof. Obtułowicz, zyskaliśmy możliwość szerszego spojrzenia na postać Marii Amparo, a to za sprawą wykorzystanych przez autorkę trudno dostępnych archiwaliów z Archivo Histórico Nacional oraz Archivo de la Real Akademia de la Historia. Ze względu na to dokumenty te są tym bardziej cenne, wśród nich „Nota sobre el casamiento de la Reina Gobernadora Dońa María Cristina con Don Fernando Muñoz, después duque de Riánsares” dotyczące potajemnego ślubu królowej regentki czy „Copia testimonio dada por Señor Konsul de España en Paris 26 de agosto de 1856 del Libro de partidas de bautismo de los hijos de María Cristina de Burbon y duque de Riánsares" zawierające informacje o chrztach dzieci państwa Muñoz, ale także liczna korespondencja pomiędzy państwem Muńoz, dziećmi i rodzicami czy 
rodzicami a nauczycielami i opiekunami książąt. Wart jest również uwagi szeroki wachlarz prasy z epoki, zarówno w języku polskim, i tu można wymienić takie tytuły, jak: „Czas”, „Gazeta Lwowska”, „Kurier Warszawski” czy „Wiadomości Polskie”, jak i hiszpańskim: „Correo de Madrid”, „Dario Español”, „El Barcelonés” czy „El Heraldo”.

Mankamentem książki jest zamieszczenie ilustracji na jej końcu, w moim odczuciu dzieło zyskałaby na atrakcyjności i większej obrazowości, gdyby ilustracje były dołączone do konkretnych rozdziałów tekstu. Taki układ pozwoliłby na dokładniejsze śledzenie historii opisanej w książce oraz możliwość łączenia tekstu z obrazem, czyli korzystanie z polisensorycznej metody odbioru. 